\title{
ANALISIS MEDIA SOSIAL TWITTER TENTANG PENDIDIKAN DARING PADA MASA PANDEMI COVID- 19 DI INDONESIA
}

\author{
(Twitter Analysis About Online Education During COVID-19 Pandemic In Indonesia)
}

\author{
Novia Permatasari ${ }^{1}$, Rihan Yosral ${ }^{2}$, Cholifa Fitri Annisa ${ }^{1}$ \\ Politeknik Statistika STIS ${ }^{1}$ \\ Badan Pusat Statistik RI ${ }^{2}$
}

\author{
Jl. Otto Iskandardinata No. 64 C, Kec. Jatinegara, Kota Jakarta Timur \\ E-mail: 16.9335@stis.ac.id
}

\begin{abstract}
ABSTRAK
PSBB yang diberlakukan oleh pemerintah pusat maupun pemerintah daerah menyebabkan perubahan aktivitas sosial yang cukup besar, salah satunya di bidang pendidikan. Hampir semua kegiatan yang semula dilakukan secara luring (luar jaringan) berubah menjadi daring (dalam jaringan). Berbagai perubahan aktivitas tersebut menuai berbagai perbincangan di media sosial, salah satunya adalah Twitter. Penelitian ini bertujuan untuk menangkap fenomena perbincangan kegiatan pendidikan yang berlangsung selama pandemic Covid-19 di Indonesia. Data yang digunakan pada penelitian ini merupakan data Twitter berbahasa Indonesia yang dikumpulkan pada tanggal 16 Maret 2020 - 31 Juli 2020. Analisis yang digunakan pada penelitian ini antara lain: analisis sentimen, social network analysis, analisis bot/spam, analisis emosi, dan analisis geografis. Data cuitan yang berhasil dikumpulkan dihasilkan berjumlah 153.204 cuitan dengan total akun sebanyak 91.306 user. Hasil sentimen menunjukkan perbincangan didominasi oleh sentimen netral, dengan tidak terdapat perbedaan signifikan dari sentimen positif dan negatif. Hasil SNA menunjukkan bahwa akun "collegemenfess" adalah aktor yang berperan sebagai influencer dan mempunyai pengaruh terbesar pada setiap user yang mengunggah cuitan terkait pendidikan daring. Hasil analisis bot/spam membagi akun menjadi lima kelas, dimana semakin besar nilai kelas, maka semakin kuat dugaan bahwa akun terindikasi bot atau pelaku spam. Proporsi akun pada lima kelas tersebut yaitu: $90.98 \%$ (kelas 0-1), 7.19\% (kelas 1-2), 0.97\% (kelas 2-3), $0.7 \%$ (kelas 3-4), $0.16 \%$ (kelas 4-5). Hasil dari analisis geografis menunjukkan lima provinsi yang memiliki sebaran cuitan isu tertinggi yaitu Jawa Barat, Jawa Tengah, Jawa Timur, DKI Jakarta, dan DI Yogyakarta, serta lima provinsi yang memiliki sebaran cuitan isu terendah yaitu Papua Barat, Maluku Utara, Gorontalo, Sulawesi Tenggara, dan Sulawesi Barat. Tiga emosi yang mendominasi cuitan mengenai pendidikan daring adalah 'Trust', 'Anticipation' dan 'Fear', dan peristiwa tertentu di bidang pendidikan mempengaruhi pergolakan jumlah emosi yang terkandung pada cuitan.
\end{abstract}

Kata kunci: sentimen, SNA, bot/spam, analisis geografi, pendidikan daring, covid-19

\section{ABSTRACT}

The PSBB imposed by the central and local governments has caused significant changes in social activities, one of which is in the field of education. Almost all activities that are carried out offline (outside the network) turned out to be online. Many changes in these activities have made a few conversations on social media, especially on Twitter. This study aims to capture the conversation of educational activity phenomenons that took place during the Covid-19 pandemic in Indonesia. The data used in this study are Indonesian language Twitter data collected on March 16, 2020 - July 31, 2020. The analyzes used in this study include: sentiment analysis, social network analysis, bot/spam analysis, emotion analysis, and geographic analysis. The tweets data collected results in 153,204 tweets with a total of 91,306 active users. The results of sentiment show that the conversation is dominated by neutral sentiment, with no difference of the positive sentiment and the negative sentiment. The SNA result shows that "collegemenfess" are actors who act as influencers and have the greatest influence on each user who posts online learning tweets. The results of the bot/spam analysis divide the accounts into five classes, the greater the class value, the stronger the suspicion that the account is indicated as a bot or spammer. 
The proportions of accounts in the five classes are: $90.98 \%$ (class $0-1$ ), $7.19 \%$ (class $1-2$ ), $0.97 \%$ (class 2-3), $0.7 \%$ (class 3-4) and $0.16 \%$ (class 4-5). The results of the post demographic analysis show that five provinces have the highest distribution of tweet issues are West Java, Central Java, East Java, DKI Jakarta and DI Yogyakarta, and the five provinces that have the lowest distribution of tweet issues are Papua, North Maluku, Gorontalo, Southeast Sulawesi, and West Sulawesi. The three emotions that dominate the tweets about online education are 'Trust', 'Anticipation' and 'Fear', and certain events in education influence the amount of emotions that a tweet contains.

Keywords: sentiment, SNA, bot/spam, geographic analysis, online learning, covid-19

\section{PENDAHULUAN}

Pembatasan Sosial Berskala Besar (PSBB) merupakan salah satu upaya pemerintah guna menekan penyebaran virus COVID-19 di Indonesia. PSBB yang diberlakukan oleh pemerintah pusat maupun pemerintah daerah menyebabkan perubahan aktivitas sosial yang cukup besar, salah satunya di bidang pendidikan. Hampir semua kegiatan yang semula dilakukan secara luring (luar jaringan) berubah menjadi daring (dalam jaringan). Kelas yang awalnya merupakan ruangan kini telah berubah bentuk menjadi "ruangan virtual" dalam bentuk platform daring seperti Google Classroom, Zoom Meeting, Google Meet dan sebagainya. Aktivitas pembelajaran daring tersebut dilakukan agar murid tetap bisa melanjutkan kegiatannya tanpa terhambat akses ke sekolah. Kegiatan-kegiatan lain seperti wisuda dan masa orientasi juga dilakukan secara online dengan berbagai penyesuaian. Berbagai aktivitas tersebut menuai berbagai perbincangan di media sosial oleh banyak pihak, baik dari murid, tenaga pengajar, maupun orang tua murid.

Media sosial merupakan media penyebaran informasi yang sangat populer, dimana satu dari tiga orang di dunia dan dua pertiga dari pengguna internet menggunakan media sosial (Ortiz-Opina, 2020). Salah satu media sosial yang paling banyak digunakan adalah Twitter, dimana seseorang dapat menulis apapun dalam 140 karakter, termasuk apa yang dialaminya selama pandemi ini. Dikutip dari pikiran-rakyat.com, pengguna Twitter mengalami peningkatan hingga 34\% pada kuartal dua tahun 2020. Twitter dapat digunakan sebagai salah satu media ekspresi yang menunjukkan respon masyarakat terhadap kegiatan pendidikan yang berlangsung selama pandemi Covid-19 di Indonesia.

Penelitian ini bertujuan untuk menangkap fenomena perbincangan mengenai kegiatan pendidikan daring yang berlangsung selama pandemi Covid-19 di Indonesia. Fenomena fenomena tersebut ditunjukkan dari volume perbincangan di media sosial Twitter serta kecenderungan opini dan emosi dari perbincangan tersebut, pola interaksi antar pengguna Twitter, serta pola persebaran cuitan-cuitan tersebut di Indonesia. Selain itu, analisis ini juga bertujuan untuk mendeteksi cuitan yang dilakukan oleh robot (spam).

\section{METODE}

Data yang digunakan pada penelitian adalah data Twitter berbahasa Indonesia yang dikumpulkan pada tanggal 16 Maret 2020 - 31 Juli 2020. Untuk mempersempit bahan diskusi, kata kunci yang digunakan dalam pengumpulan data yaitu: orientasi online, ospek online, sekolah online, sidang online, wisuda online, kuliah daring, pjj, pembelajaran jarak jauh, study from home, orientasi daring, ospek daring, sekolah daring, dan wisuda daring. Data Twitter yang dikumpulkan kemudian dilakukan pre-processing data sebelum analisis lebih lanjut. Analisis yang digunakan pada penelitian ini antara lain: analisis sentimen, social network analysis, analisis bot/spam, analisis emosi, dan analisis geografis. Kerangka pikir yang digunakan pada penelitian ini dapat dilihat pada Gambar $\mathbf{1}$. 


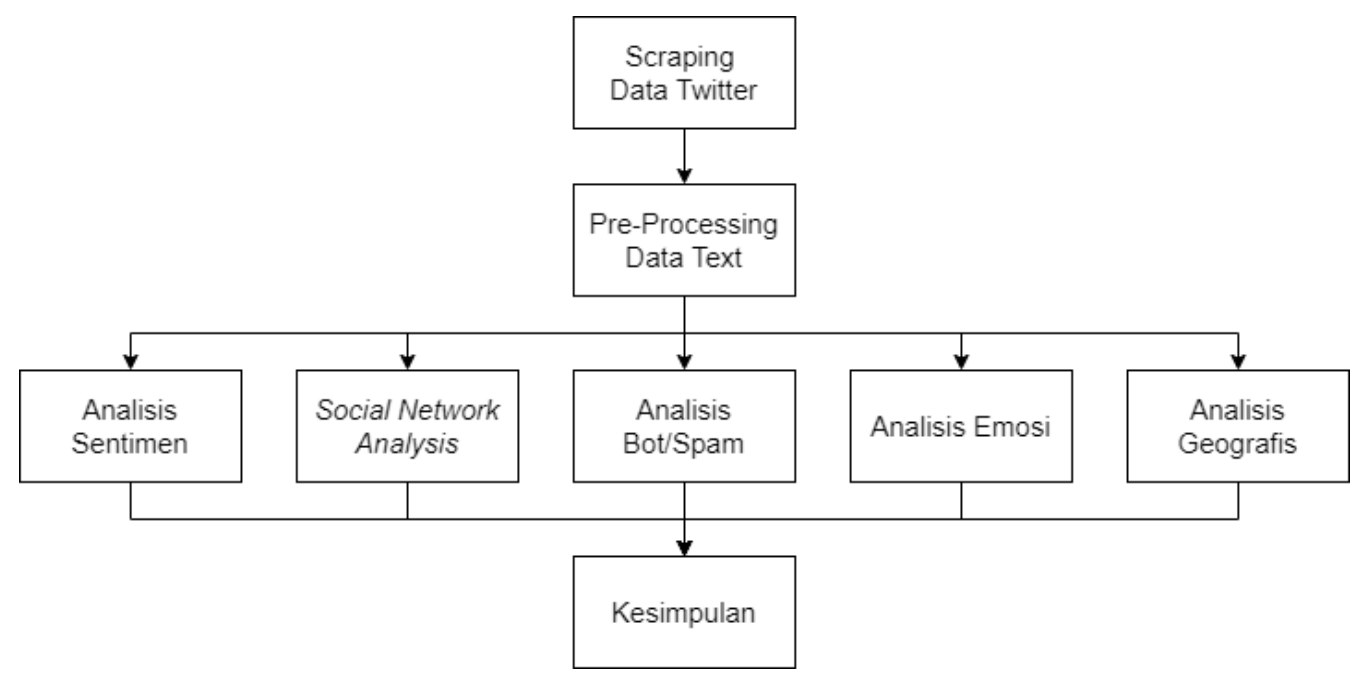

Gambar 1. Kerangka Pikir Penelitian.

Pada tahap pre-processing, dilakukan beberapa bentuk text processing guna meningkatkan kualitas data saat digunakan untuk analisis (Ferdiana, 2019). Tahap text processing yang dilakukan antara lain: menghapus simbol dan tanda baca; tokenizing, case folding, stemming dan stopword removal. Tokenizing bertujuan untuk membagi tweet menjadi kata-kata yang biasa disebut token. Case folding merupakan proses merubah kata-kata menjadi satu bentuk yang sama, yaitu huruf kecil. Stemming merupakan proses mendapatkan kata dasar dengan menghilangkan imbuhan pada kata. Stopword removal digunakan untuk menghilangkan kata-kata umum yang tidak memiliki pengaruh signifikan dalam tweet. Setelah cleaning dan pre-processing selesai, dilakukan pencarian wawasan terkait fakta yang mendukung analisis secara keseluruhan terkait pendidikan daring pada masa pandemi COVID19.

Analisis sentimen merupakan proses penggalian opini, sentimen, dan emosi yang disampaikan secara tekstual (Liu, 2010). Analisis dilakukan dengan metode leksikon (berbasis kamus). Kamus kata positif dan kata negatif dicocokkan ke masing-masing kata dalam kalimat untuk menghitung skor sentimennya. Skor sentimen lebih dari nol menunjukkan sentimen positif, begitu pula sebaliknya. Skor sentimen sama dengan nol menunjukkan sentimen yang netral. Analisis sentimen digunakan untuk melihat pendapat atau kecenderungan opini dari proses pendidikan di masa pandemi.

Social Network Analysis (SNA) adalah proses pemetaan dan pengukuran relasi antara aktor, dengan kata lain analisis jaringan sosial yang berkaitan dengan bentuk struktur dan pola interaksi entitas di dalamnya (Freeman, 1979). Analisis ini digunakan untuk kebutuhan pengambilan informasi, termasuk hubungan interaksi dan pertemanan antar akun pengguna, dimana interaksi antar akun dan hubungan pertemanan dapat direpresentasikan sebagai graf (Otte \& Rousseau, 2002). Berdasarkan Freeman (1979), ada beberapa macam metode untuk merepresentasikan graf, salah satunya adalah metode analisis sentralistis. Metode ini memiliki tiga konsep utama analisis, yaitu degree, closeness, dan betweenness.

Analisis akun bot/spam digunakan untuk membedakan antara akun user Twitter yang merupakan akun bot/spam dan akun pengguna yang sah (Perdana, et.al). Akun bot/spam dilabeli skor dengan rentang 0-5 menggunakan API mesin pembelajaran Botometer yang dikembangkan oleh Indiana University Network Science Institute (Sayyadiharikandeh, 2020). Skor tersebut mengindikasikan probabilitas apakah akun Twitter adalah akun bot/spam, semakin tinggi nilai maka semakin besar kemungkinan ketidakabsahan akun tersebut. 
Analisis emosi dilakukan menggunakan pendekatan leksikon berdasarkan roda emosi Plutchik (Plutchik \& Kellerman, 1980): joy (kebahagiaan), trust (kepercayaan), fear (ketakutan), surprise (keterkejutan), sadness (kesedihan), disgust (ketidaksukaan), anger (kebencian), anticipation (pencegahan). Masing-masing kategori emosi dipetakan pada cuitan yang telah diperoleh untuk mendapatkan informasi emosi apa saja yang terkandung dari keseluruhan cuitan, beserta kaitannya dengan situasi yang terjadi sesuai waktu cuitan tersebut.

Analisis geografis digunakan untuk menganalisis pola persebaran cuitan berdasarkan geografis wilayah di Indonesia. Dari sini kita dapat mengetahui wilayah mana saja yang paling banyak memberikan kontribusi terhadap cuitan terkait pendidikan daring di masa pandemi COVID-19. Selain itu kita dapat mengaitkannya dengan fenomena pemerataan infrastruktur jaringan internet dan perangkat ponsel disebabkan pola hubungannya yang berbanding lurus dengan persebaran geografi cuitan pengguna (Yusrizal, 2016).

\section{HASIL DAN PEMBAHASAN}

Data yang dihasilkan berjumlah 153.204 cuitan dengan total akun sebanyak 91.306 user. Dari data dihasilkan frekuensi 5 kata teratas paling sering muncul yaitu, online sebanyak 67.192 pengulangan kata, daring sebanyak 45.220 pengulangan kata, pjj sebanyak 38.119 pengulangan kata, sekolah sebanyak 37.007 pengulangan kata, dan kuliah sebanyak 34.776 pengulangan kata. Visualisasi kata yang paling sering muncul (tanpa kata kunci) serta tren total cuitan dapat dilihat pada Gambar 2 dan Gambar 3.



Gambar 2. Wordcloud Cuitan Data Twitter.

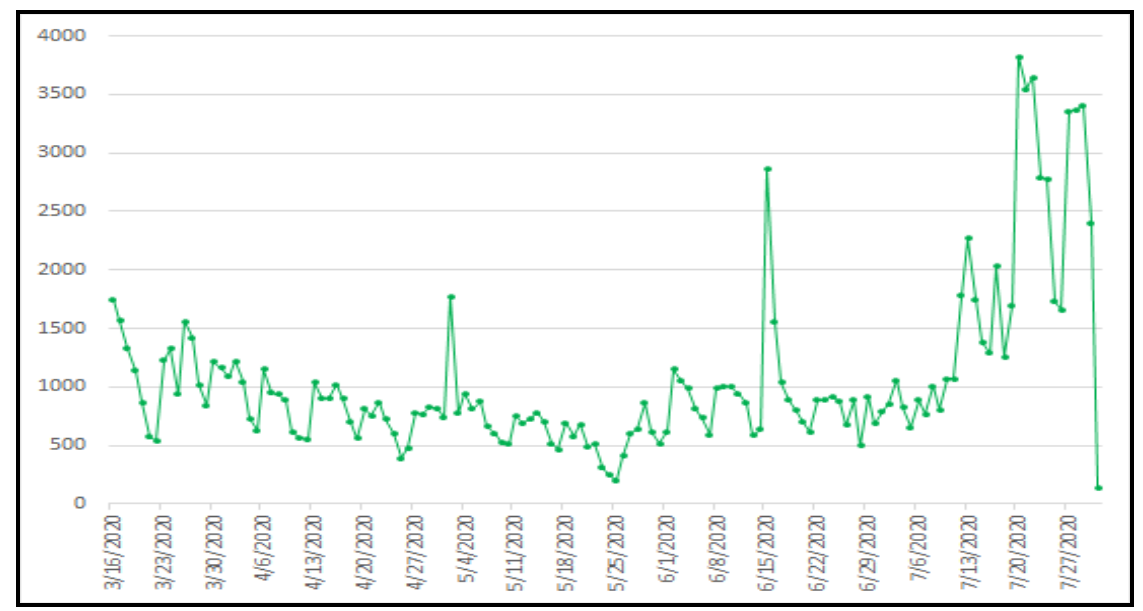

Gambar 3. Tren Jumlah Cuitan Data Twitter. 
Pada worldcloud, kata yang paling besar dapat diasumsikan sebagai kata yang mewakili topik pembicaraan pada Twitter. Topik pembicaraan berkisar pada pihak yang terlibat pada bidang pendidikan, seperti \#dosen, \#guru, \#mahasiswa, dan \#anak. Kata \#ajar (yang berasal dari kata belajar/mengajar/pembelajaran) dan \#tugas menunjukkan kegiatan di bidang pendidikan. Serta kata \#kampus, \#rumah, dan \#kelas menunjukkan lokasi kegiatan. Terlihat pula ada beberapa kata sifat seperti \#semangat, \#bingung, \#sedih, \#enak dan \#susah.

Pada tren jumlah cuitan, terdapat lonjakan jumlah cuitan pada hari-hari tertentu, baik meningkat maupun menurun secara drastis. Lonjakan tersebut muncul bersamaan dengan waktu kejadian penting di bidang pendidikan, seperti Hari Pendidikan Nasional (02/05/2020), penyelenggaraan UTBK-SBMPTN (30/05/2020), awal tahun ajaran baru (29/06/2020), dan rencana mundurnya Muhammadiyah-NU-PGRI sebagai organisasi penggerak Kemendikbud (29/07/2020). Hal ini mengindikasikan bahwa adanya peristiwa tertentu dapat memicu lonjakan jumlah cuitan di Indonesia.

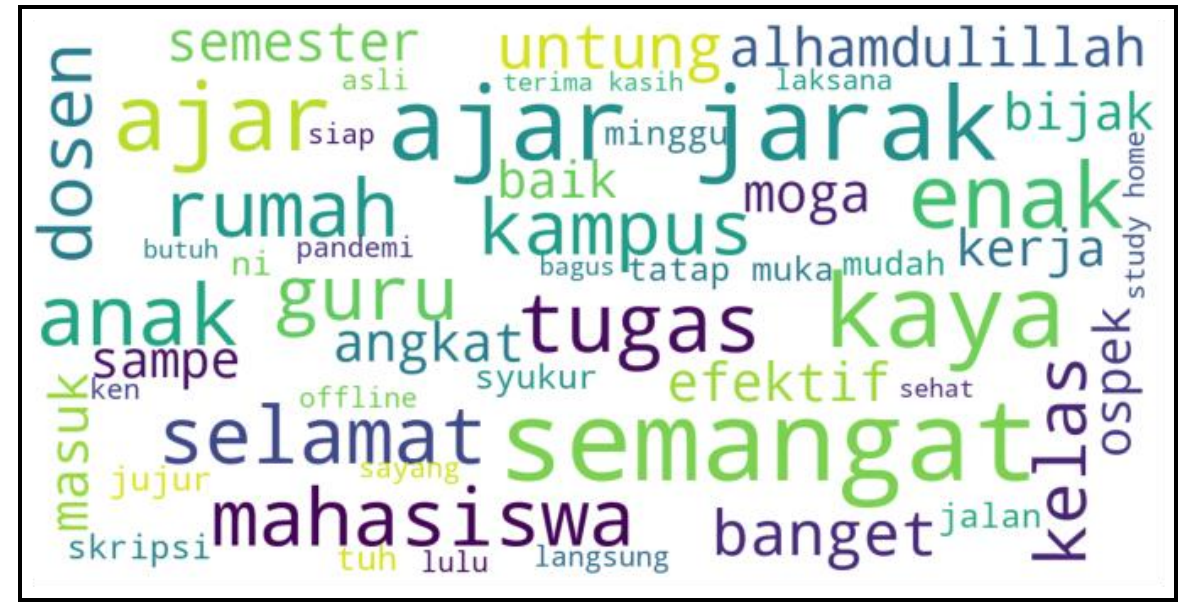

Gambar 4. Wordcloud Cuitan dengan Sentimen Positif.

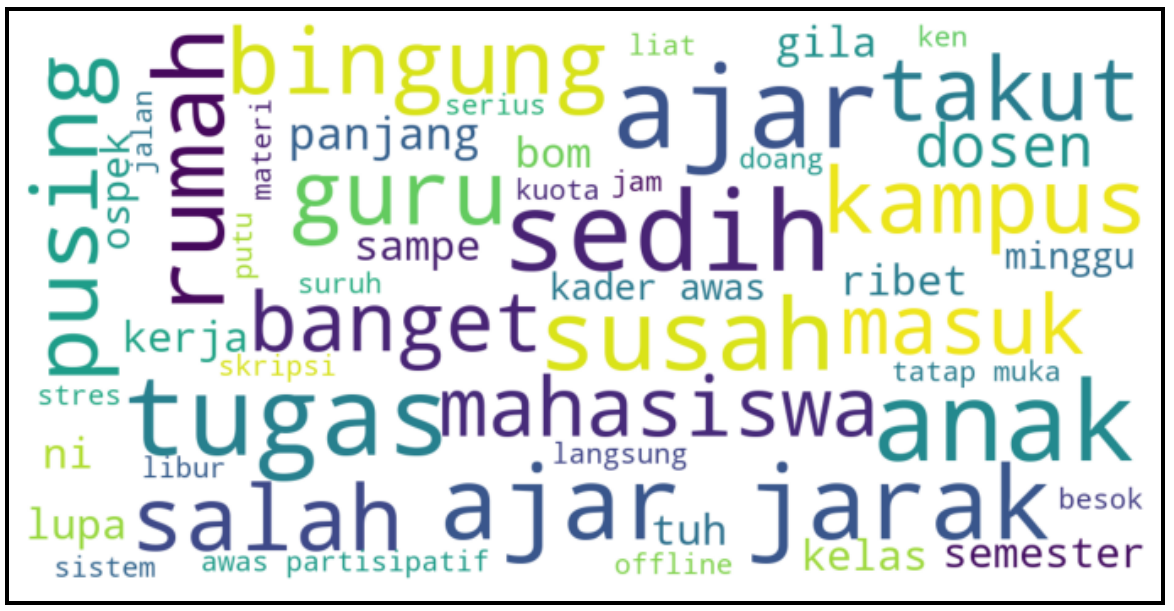

Gambar 5. Wordcloud Cuitan dengan Sentimen Negatif.

Perbincangan tentang pendidikan di masa pandemi didominasi oleh sentimen netral sebesar 61,2 persen, sentimen positif sebesar 19,9 persen, dan sentimen negatif sebesar 18,9 persen. Kata-kata yang sering muncul pada sentimen negatif didominasi oleh ekspresi keluhan, seperti: sedih, susah, takut, bingung, dan salah. Kata-kata yang sering muncul pada sentimen positif diantaranya: semangat, alhamdulillah, syukur, dan selamat. 


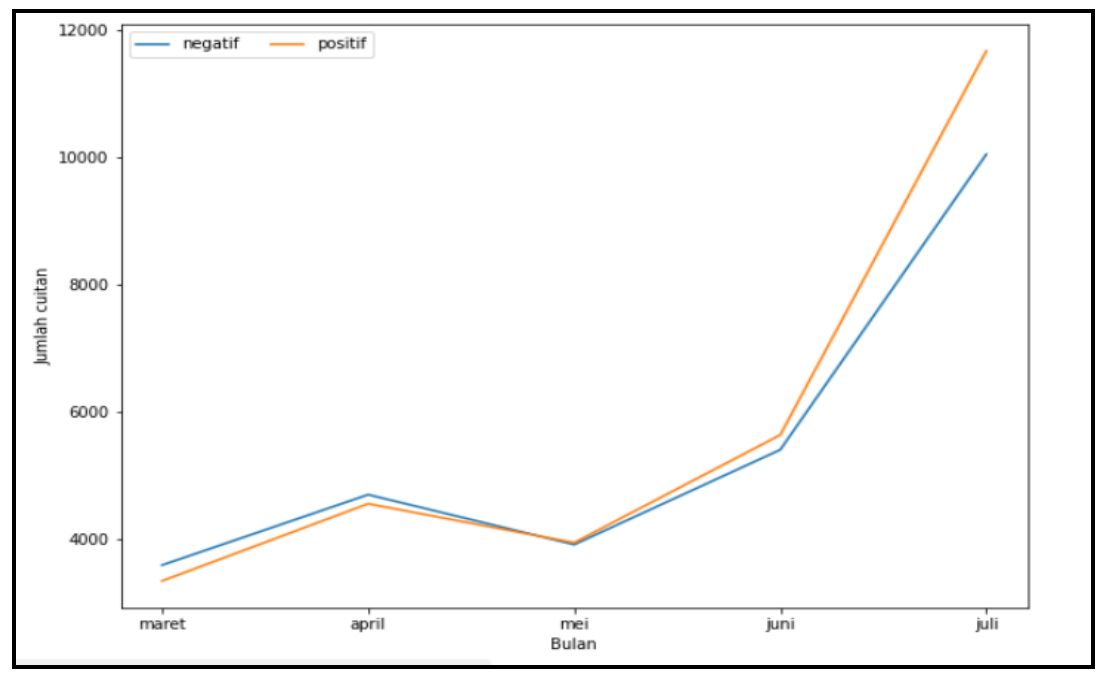

Gambar 6. Tren Cuitan Berdasarkan Sentimen Bulanan.

Tren tweet dengan sentimen negatif dan positif dapat dilihat pada Gambar 4 dan Gambar 5. Pada data agregat bulanan, terdapat perubahan kecenderungan antara tweet dengan sentimen positif dan negatif pada rentang waktu Maret - Juli. Pada bulan Maret dan April, tweet dengan sentimen negatif lebih banyak dari tweet dengan sentimen positif. Pada bulan Mei, tweet dengan sentimen positif dan negatif memiliki jumlah yang hampir sama. Sedangkan pada bulan Juni dan Juli, tweet dengan sentimen positif lebih banyak dari tweet dengan sentimen negatif dengan selisih tertinggi berada di Bulan Juli.

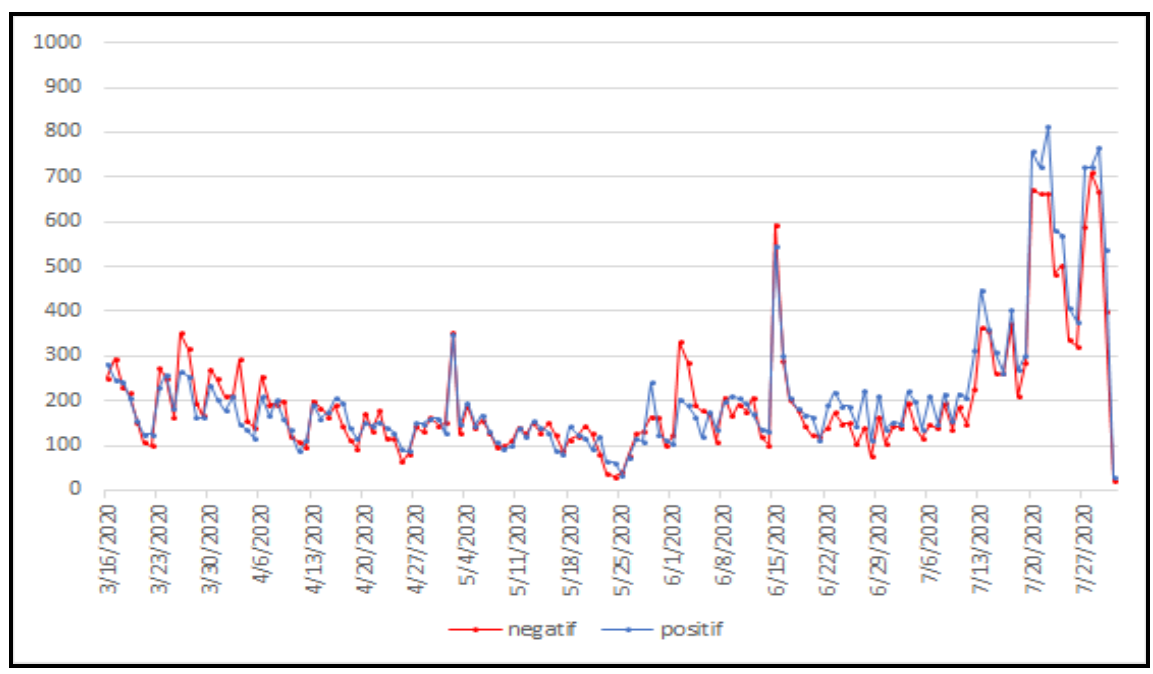

Gambar 7. Tren Cuitan Berdasarkan Sentimen Harian.

Dengan melihat tren tweet harian, terlihat bahwa terdapat selisih antara tweet ber sentimen positif dan negatif di beberapa tanggal. Tweet dengan sentimen positif cenderung lebih tinggi dari tweet dengan sentimen negatif di akhir Bulan Juli. Hal ini bertepatan dengan dimulainya tahun ajaran baru. Sedangkan tweet dengan sentimen negatif cenderung lebih tinggi dari tweet dengan sentimen positif di akhir Bulan Maret dan awal Bulan Juni.

Berdasarkan analisis Social Network Analysis (SNA) didapatkan jumlah titik (node) sebanyak 35.414 node yang memiliki total koneksi (edge) sebanyak 22.197 edge dengan kepadatan jaringan (density graph) sebesar 3.539 e-05. Dari analisis metode sentralitas, dihasilkan tiga statistik yaitu degree of centrality, betweenness centrality, dan closeness centrality yang masing-masing mencakup urutan nama akun berdasarkan peringkat degreenya dalam tabel berikut. 
Tabel 1. Peringkat tiga teratas berdasarkan analisis centrality

\begin{tabular}{cccccc}
\hline \multicolumn{2}{c}{ Degree of Centrality } & \multicolumn{2}{c}{ Betweeness Centrality } & \multicolumn{2}{c}{ Closeness Centrality } \\
\hline Nama Akun & $n$ & Nama Akun & Degree & Nama Akun & Degree \\
\hline collegemenfess & 2044 & collegemenfess & 0.0875 & collegemenfess & 0.0290 \\
subtanyarl & 430 & FirstMediaCares & 0.0803 & naufalnianwar & 0.0148 \\
schfess & 245 & Indihome & 0.0736 & agustinyanti & 0.0147 \\
\hline
\end{tabular}

Dari daftar akun aktif yang mengunggah cuitan terkait pendidikan daring, didapatkan bahwa tiga akun teratas berdasarkan degree of centrality yaitu akun "collegemenfess", "subtanyarl", dan "schfess". Jumlah $n$ menunjukkan jumlah dari aktivitas yang terhubung dari setiap node sehingga, dapat disimpulkan bahwa tiga akun tersebut adalah akun pengguna yang terpopuler atau yang paling sering melakukan aktivitas unggahan terkait cuitan pendidikan daring.

Berdasarkan betweenness centrality didapatkan bahwa tiga akun teratas berdasarkan ukuran tersebut yaitu akun "collegemenfess", "FirstMediaCare", dan "Indihome". Jumlah degree pada betweenness centrality menunjukkan besaran titik tengah berdasarkan posisi pada jalur antara dua atau lebih node pada graf, sehingga dapat disimpulkan bahwa tiga akun pengguna tersebut adalah akun pengguna yang berperan penting sebagai perantara pada setiap node pengguna menuju jaringan pusat.

Berdasarkan closeness centrality diperoleh tiga akun teratas secara berurutan yaitu akun "collegemenfess", "naufalnianwar", "agustinyanti". Jumlah degree menunjukkan jarak minimum untuk mencapai setiap node pada jaringan, sehingga dapat disimpulkan bahwa tiga akun tersebut adalah akun dengan jarak paling dekat antara setiap akun yang mengunggah cuitan terkait pendidikan daring.

Jika dilihat secara keseluruhan, dari banyaknya jumlah aktivitas unggahan, besarnya degree perantara antar akun, dan besarnya jarak minimum antar akun, maka dapat disimpulkan bahwa akun "collegemenfess" adalah aktor yang berperan sebagai influencer dan mempunyai pengaruh terbesar pada setiap akun yang mengunggah cuitan terkait pendidikan daring.

Tabel 2. Rangkuman Analisis Bot Akun Twitter

\begin{tabular}{cccccccccc}
\hline $\begin{array}{c}\text { Bot/spam } \\
\text { Class }\end{array}$ & Author & \%Author & Posts & \%Post & Retweeted & Mentions & Replies & Likes & $\begin{array}{c}\text { Bot/spam } \\
\text { Scores }\end{array}$ \\
\hline $0-1$ & 58.095 & 90,98 & 93.202 & 92,55 & 192.806 & 42.170 & 129.711 & 612.818 & 1,05 \\
$1-2$ & 4.589 & 7,19 & 6.127 & 6,08 & 3.737 & 2.592 & 5.610 & 17.504 & 1,67 \\
$2-3$ & 622 & 0,97 & 800 & 0,79 & 187 & 342 & 743 & 1.210 & 2,58 \\
$3-4$ & 453 & 0,7 & 478 & 0,48 & 96 & 170 & 627 & 481 & 3,47 \\
$4-5$ & 99 & 0,16 & 94 & 0,1 & 40 & 56 & 120 & 252 & 4,55 \\
\hline
\end{tabular}

Dari 91.306 akun yang mengunggah cuitan terkait pendidikan daring, terdeteksi sejumlah 63.585 akun yang masih aktif setelah rentang waktu tersebut, dengan total 100,701 cuitan. Banyaknya akun yang tidak aktif sebanyak 27.721 akun (30,36\% dari seluruh akun) mengindikasikan masih banyaknya akun fake yang hanya aktif sementara waktu di Twitter. 
Dibandingkan dengan kelas lainnya, kelas interval 3-4 memiliki rasio likes terhadap posts terkecil, yaitu sebesar $1,006 \%$. Hal ini mengindikasikan skor kelas interval akun-akun tersebut mendekati perilaku bot/spam, yaitu cuitan yang banyak namun hanya mendapat sedikit like.

Berdasarkan 10-50 sampel akun yang peneliti ambil dari kelas interval 3-4 dan 4-5, akun tersebut didominasi akun dengan profil sebagai fanbase selebritas tertentu atau gamers. Akun tersebut melakukan perilaku spam berupa retweet atau cuitan yang banyak dalam rentang waktu sehari (lebih dari 15 retweet), misalkan akun dengan screen_name @miniewoodzeu, @pow_shine, @PunyaTuyul, @rranjk, @GamesRedDeer dan lain-lain.

Proporsi akun pada kelas interval 4-5 sangat kecil (0.16\%) dibandingkan jumlah proporsi kelas interval 0-1 sampai dengan 2-3 (99.14\%). Dari angka tersebut dapat diketahui jika cuitan masih didominasi bukan oleh bot/spam, dengan rata-rata tertimbang skor bot/spam keseluruhan sebesar 1,13. Skor bot yang rendah menandakan bahwa percakapan dapat dianggap terjadi secara cukup natural tanpa pola pengulangan khusus seperti akun bot/spam.

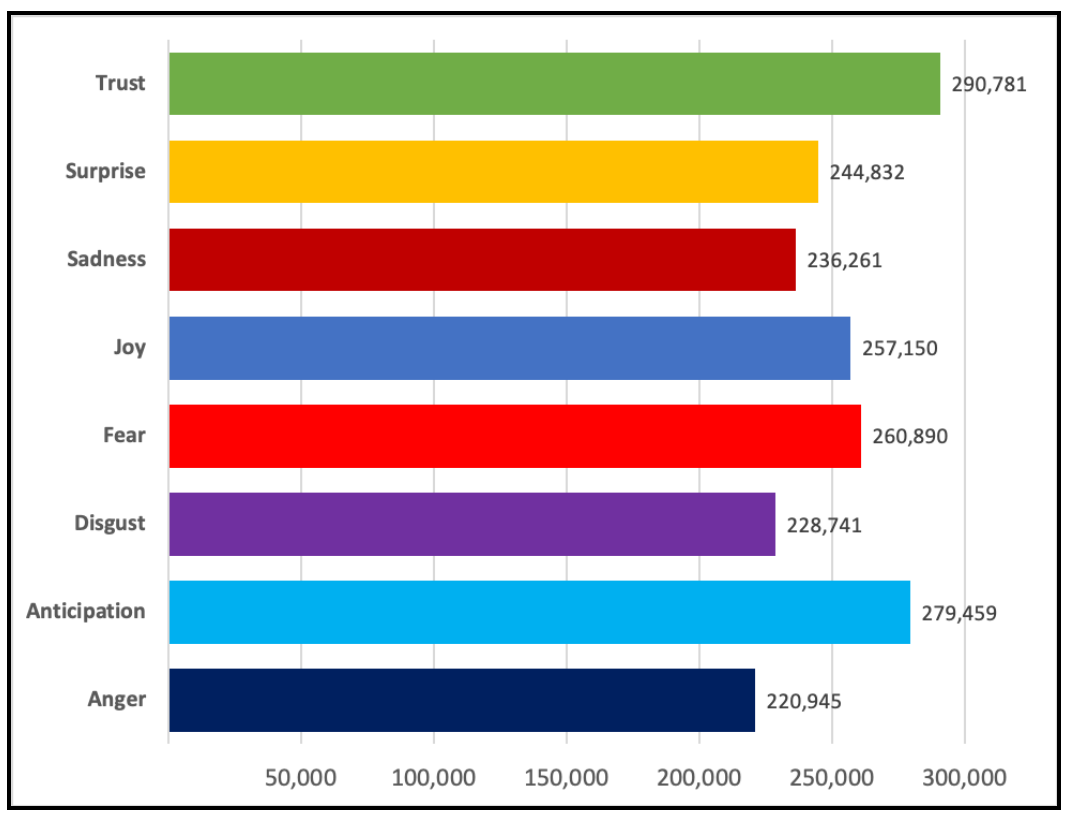

Gambar 8. Jumlah Cuitan Per Kategori Emosi

Secara agregat emosi yang paling mendominasi secara urut adalah "Trust" "Anticipation" - "Fear" - "Joy" - "Surprise" - "Sadness" - "Disgust" - "Anger". Hal ini menggambarkan bahwa ternyata emosi yang bersifat negatif seperti 'Anger' ataupun 'Disgust' terhadap pendidikan daring justru tidak mendominasi pada cuitan pemilik akun, meskipun muncul berbagai berita persoalan ekonomi dan politik di tengah pandemi. Mereka lebih mengungkapkan emosi yang mewakili berbagai ungkapan rasa syukur ataupun kecemasan sebagaimana terlihat pada Gambar 4 dan Gambar 5. seperti "alhamdulillah", "untung", "terima kasih", "syukur", "enak", lalu "bingung", "takut", "pusing", "ribet", dan "susah". 


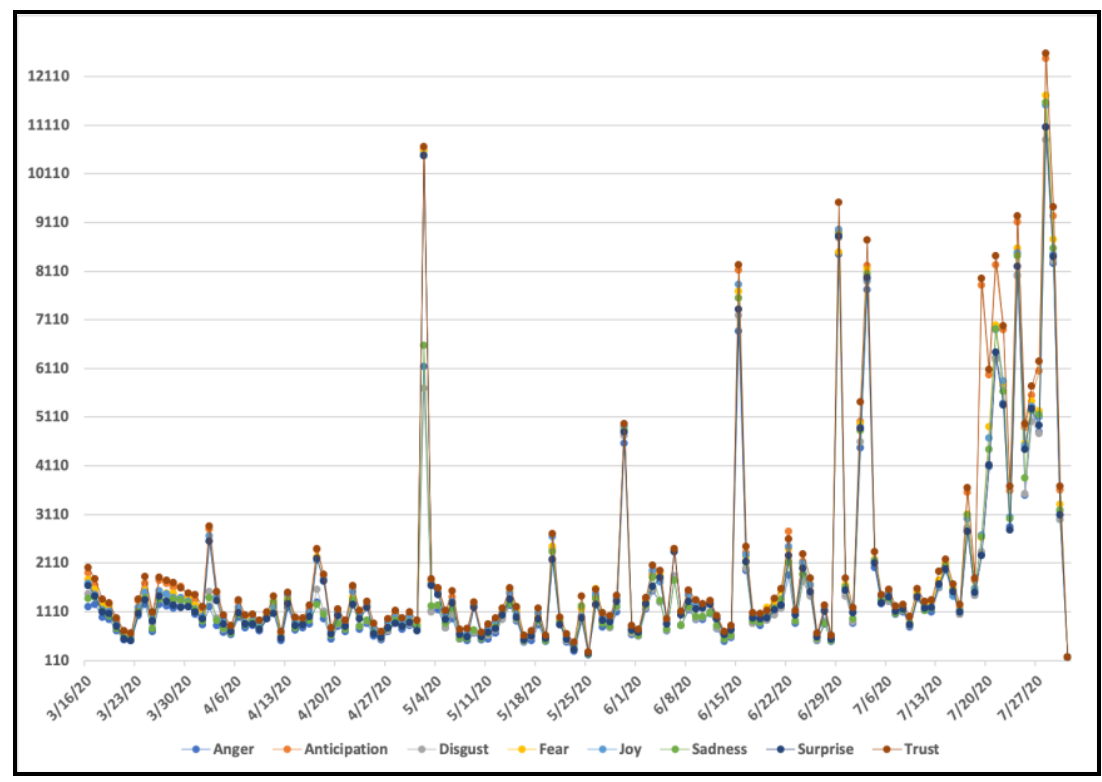

Gambar 9. Tren Jumlah Cuitan Berdasarkan Kategori Emosi Per Hari.

Secara umum tren pada jumlah emosi pada cuitan per hari berpola sama dengan jumlah emosi pada cuitan secara agregat. Emosi "Trust" per harinya selalu mendominasi, dan sebaliknya dengan emosi "Anger" yang hampir selalu berada di urutan terbawah. Cuitan beremosi "Trust" secara umum juga mendominasi berbagai spike yang muncul ketika adanya peristiwa yang berkaitan dengan pendidikan, seperti Hari Pendidikan Nasional (02/05/2020), penyelenggaraan UTBK-SBMPTN (30/05/2020), awal tahun ajaran baru (29/06/2020), disusul emosi "Anticipation", "Joy", dan "Fear". Menariknya, justru cuitan berisi emosi "Trust" langsung turun tajam per 29-30 Juli 2020 (9,431 ke 176 cuitan) dan emosi "Anger" hanya turun sedikit per 29-30 Juli 2020 (8,259 ke 3,010 cuitan) ketika adanya berita mundurnya beberapa organisasi penggerak pendidikan Indonesia.

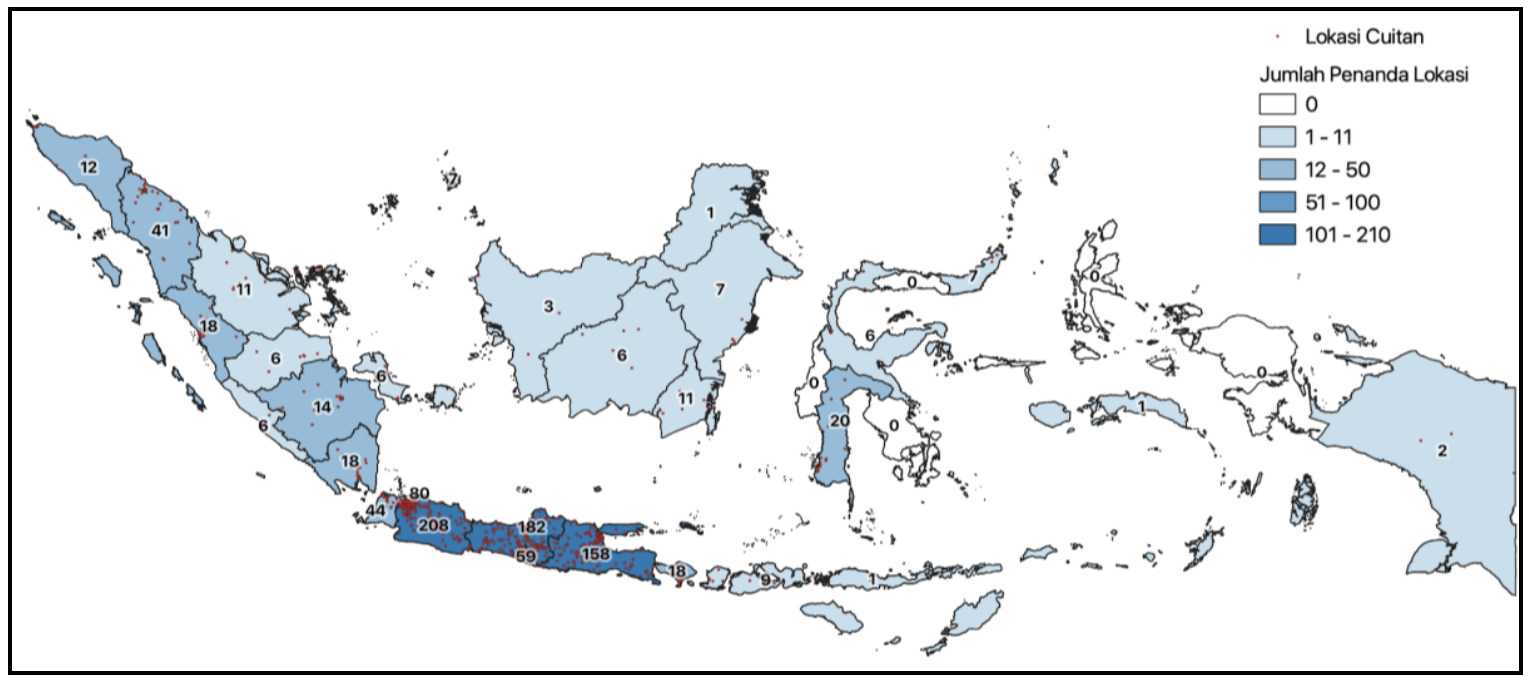

Gambar 10. Persebaran Jumlah Titik Lokasi Cuitan di Indonesia.

Dari 153.204 cuitan, hanya ada 962 cuitan yang mencantumkan titik geolokasi valid dan berada di wilayah Indonesia. Dari total titik tersebut, mayoritas berada di Pulau Jawa sebanyak 719 titik lokasi cuitan (non-unik). Hal tersebut mengindikasikan bahwa persebaran jaringan internet untuk bermain Twitter masih tidak merata di luar Pulau Jawa, terlihat dari sebaran titik merah pada gambar yang masih lengang dibandingkan luas wilayah provinsinya. Pola titik lokasi 
cuitan beraglomerasi di Pulau Jawa. Pola sebaran lokasi cuitan juga cenderung dekat dengan ibukota provinsi atau kota-kota besar saja seperti Padang, Medan, Banjarmasin, Balikpapan, Makassar, Manado, Serang, Surabaya, dan lain-lain. Provinsi yang paling banyak mencuit dengan informasi geolokasi adalah Jawa Barat (208), disusul oleh Jawa Tengah (179), Jawa Timur (158) dan DKI Jakarta (78). Uniknya, hampir 60\% total cuitan yang memiliki info geografis seperti alamat atau titik koordinat GPS di Jawa Barat berasal dari Kabupaten/Kota Bekasi.

\section{KESIMPULAN}

Data cuitan yang berhasil dikumpulkan dihasilkan berjumlah 153.203 cuitan dengan total akun sebanyak 91.306 user. Hasil sentimen menunjukkan perbincangan didominasi oleh sentimen netral, dengan tidak terdapat perbedaan topik pembicaraan dari ketiga sentimen. Hasil SNA menunjukkan bahwa akun "collegemenfess" adalah aktor yang berperan sebagai influencer dan mempunyai pengaruh terbesar pada setiap akun yang mengunggah cuitan terkait pendidikan daring. Hasil analisis bot/spam membagi akun menjadi lima kelas, dimana semakin besar nilai kelas, maka semakin kuat dugaan bahwa akun terindikasi bot atau pelaku spam. Proporsi akun pada lima kelas tersebut yaitu: $90.98 \%$ (kelas $0-1$ ), $7.19 \%$ (kelas 1-2), $0.97 \%$ (kelas $2-3$ ), $0.7 \%$ (kelas $3-4$ ), $0.16 \%$ (kelas 4-5). Hasil dari analisis geografis menunjukkan lima provinsi yang memiliki sebaran cuitan isu tertinggi yaitu Jawa Barat, Jawa Tengah, Jawa Timur, DKI Jakarta, dan DI Yogyakarta, serta lima provinsi yang memiliki sebaran cuitan isu terendah yaitu Kalimantan Utara, Maluku, Nusa Tenggara Timur, Papua, dan Kalimantan Barat.

\section{DAFTAR PUSTAKA}

Otte, E. \& Rousseau, R. (2002). Social Network Analysis: A Powerful Strategy, Also For The Information Sciences. Journal of Information Science, No. 28, page 443-455.

Ferdiana, Ridi et.al. (2019). Dataset Indonesia untuk Analisis Sentimen. Jurnal Nasional Teknik Elektro dan Teknologi Informasi Vol. 8 No. 4.

Freeman, L.C. (1979). Centrality in social networks: I. Conceptual Clarification. Journal of Social Networks, vol 1. p. 125.

Indurkhya, N. \& Damerau, F. J. (2010). Handbook of Natural Language Processing. Boca: Taylor and Francis Group, LLC.

Mohammad, S., \& Pfahringer, B. (2016). Determining Word-Emotion Associations from Tweets by MultiLabel Classification. Proceeding of the 2016 IEEE/WIC/ACM International Conference on Web Intelligence (WI 2016). 2016. Omaha, Nebraska, USA.

Perdana, Rizal Setya et.al. (2015). Bot Spammer Detection in Twitter Using Tweet Similarity and Time Interval. Jurnal Ilmu Komputer dan Informasi 8(1):20-26

Plutchik, R. \& Kellerman, H. (1980). Emotion: Theory, Research and Experience. New York: Academic Press.

Ortiz-Ospina, E. (2020) The rise of social media. Cited in: https://ourworldindata.org/rise-of-social-media.

Sayyadiharikandeh, M. et.al. (2020). Detection of Novel Social Bots by Ensembles of Specialized Classifiers. Proceeding of 29th ACM International Conference on Information and Knowledge Management (CIKM 2020).

Sinuhaji, Julkifli. (2020). Dunia Terisolasi Pandemi Covid-19, Pengguna Twitter Meningkat. Cited in https://www.pikiran-rakyat.com/teknologi/pr-01634954/dunia-terisolasi-pandemi-covid-19-penggunatwitter-meningkat?page=all. diakses pada 28/08/2020 
Yusrizal. (2016). Survey Penggunaan Teknologi dan Komunikasi di Wilayah Perbatasan. Jurnal Teknologi Informasi dan Komunikasi Vol. 5 No. 1 Juni 2016: 13-28. Kementerian Komunikasi dan informatika, Medan. 